\title{
Using globally threatened pelagic birds to identify priority sites for marine conservation in the South Atlantic Ocean
}

4 Maria P. Dias ${ }^{1, *}$, Steffen Oppel ${ }^{2}$, Alexander L. Bond ${ }^{3}$, Ana P. B. Carneiro ${ }^{1}$, Richard J. Cuthbert $^{3}$, Jacob Gonzáles-Solís ${ }^{4}$, Ross M. Wanless ${ }^{5,8}$, Trevor Glass ${ }^{6}$, Ben Lascelles ${ }^{1}$, Cleo

6 Small $^{2}$, Richard A. Phillips ${ }^{7}$ and Peter G. Ryan ${ }^{8}$

8

${ }^{1}$ BirdLife International, Cambridge, UK

${ }^{2}$ RSPB Centre for Conservation Science, Cambridge, UK

${ }^{3}$ RSPB Centre for Conservation Science, Sandy, UK

12

${ }^{4}$ University of Barcelona, Barcelona, Spain

${ }^{5}$ BirdLife South Africa, Cape Town, South Africa

${ }^{6}$ Tristan da Cunha Conservation Department, Edinburgh of the Seven Seas, Tristan da Cunha, South Atlantic

${ }^{7}$ British Antarctic Survey, Cambridge, UK

${ }^{8}$ Percy FitzPatrick Institute of African Ornithology, DST-NRF Centre of Excellence, University of Cape Town, Cape Town, South Africa

18

*Corresponding author: BirdLife International, David Attenborough Building, Pembroke Street, Cambridge, CB3 3QZ, UK; phone number: +44 (0)1223 747540; maria.dias@birdlife.org,

\section{Abstract}

24 The Convention on Biological Diversity aspires to designate $10 \%$ of the global oceans as Marine Protected Areas (MPAs), but so far few MPAs protect pelagic species in the high seas. Transparent scientific approaches are needed to ensure that these encompass areas with high biodiversity value. Here we used the distribution of all globally threatened seabirds breeding in a centrally located archipelago (Tristan da Cunha) to provide guidance on where MPAs could be established in the South Atlantic Ocean. We combined year-round tracking data from six species, and used the systematic conservation-planning tool Zonation to 
delineate areas that would protect the largest proportion of each population. The areas used most intensively varied among species and seasons. Combining the sites used by all six species suggested that the most important areas of the South Atlantic are located south of South Africa, around the central South Atlantic between $30^{\circ} \mathrm{S}$ and $55^{\circ} \mathrm{S}$, and near South America. There was no overlap between the identified areas and any of the existing MPAs in the South Atlantic. The conservation of these highly mobile pelagic species cannot be achieved by single countries, but requires a multi-national approach at an ocean-basin scale.

Keywords: Important Bird and Biodiversity Areas; Marine Protected Areas; Seabirds; Threatened species; Tristan da Cunha

\section{Introduction}

The designation of Marine Protected Areas (MPAs) is an important mechanism to conserve marine areas of biological importance (Game et al. 2009). In 2016, MPAs covered 5.6\% of the global ocean surface (Boonzaier and Pauly 2016; Juffe-Bignoli et al. 2014), which remains substantially less than the $10 \%$ envisioned by the Convention on Biological Diversity by 2020 (CBD 2010). Most existing MPAs are in near-shore waters, and there are very few MPAs to protect the diverse pelagic ecosystems of the world (Game et al. 2009). Many of the world's most charismatic animals such as marine mammals, seabirds, turtles, sharks, and tuna inhabit pelagic ecosystems. Because these species often face a diverse range of pressures due to their extensive movements (Croxall et al. 2012; Tuck et al. 2003; Žydelis et al. 2009), many pelagic species are now highly threatened, and there is a critical need to identify and designate an effective global network of pelagic MPAs to protect these species and the food webs on which they depend.

The processes by which MPAs are identified, designated, and enforced are complex

56 (Game et al. 2010; Hobday et al. 2014; Kaplan et al. 2010). The approaches differ enormously depending on whether MPAs are designated opportunistically, if their location is based on strict scientific criteria that aim to maximise biodiversity benefits (BirdLife International 2010; Jessen et al. 2011; Smith et al. 2014), or whether the social and economic costs are considered in the site selection process (Ban 2009; Mazor et al. 2014). Due to the commitment of many national governments to protect a certain proportion of the marine area 
within their jurisdiction, there is the risk that large MPAs are designated that fail to meet scientific principles of systematic conservation planning (Barr and Possingham 2013; Devillers et al. 2014). To avoid the protection of large marine areas that are of comparatively low biodiversity value and do not adequately represent the full range of marine ecosystems, it is fundamental that identification of MPAs is based on transparent scientific approaches (Fernandes et al. 2005; Gleason et al. 2010; Klein et al. 2009).

Many species depending on pelagic ecosystems can travel large distances (Block et al. 2011). However, long-term studies have revealed considerable site fidelity or consistent use of well-defined habitats for many species or populations, despite their mobility (Arthur et al. 2015; Dias et al. 2011; Wakefield et al. 2015). Sites and habitats used persistently by multiple species or populations would be suitable candidates for enhanced management or protection as an MPA (Lascelles et al. 2014). Understanding the spatial distribution of pelagic species is therefore crucial for the identification of sites with high biodiversity value; however, due to the logistical difficulties in sampling pelagic areas, our knowledge of site use by many marine animals is comparatively poor. The movements and distribution of large and charismatic mega-fauna, including marine mammals or seabirds, is much better understood than that of invertebrates and most fish (Chown et al. 1998; Mora et al. 2008; Tittensor et al. 2010). Moreover, seabirds can act as umbrella species and represent the spatial distribution of diverse organisms at lower trophic levels (Aslan et al. 2015; Williams et al. 2014). By considering seabirds as a surrogate group representing wider marine biodiversity, robust analyses of their spatial distribution should therefore avoid the designation of MPAs in areas of low biodiversity value.

The South Atlantic Ocean is a globally important ecosystem with a high diversity of seabirds, fish, and marine mammals (Trebilco et al. 2011; Williams et al. 2014), but has a relatively poor coverage of MPAs, despite demonstrated high biodiversity especially around the Falkland Islands (Juffe-Bignoli et al. 2014), and off the coast of South America (Ramos et al. 2016; Tancell et al. 2016; Yorio 2009) and southern Africa (Ludynia et al. 2012). Given its global importance for pelagic biodiversity, delineating MPAs using objective criteria based on umbrella species would fill a critical gap in terms of conservation. Here we use a unique dataset covering the year-round distribution of all globally threatened seabirds breeding in a centrally located archipelago in the South Atlantic (Tristan da Cunha) to fill this critical data gap and provide guidance on where potential MPAs could be established in the region. The seabird community of Tristan da Cunha represents a variety of trophic levels and 
foraging guilds, and the spatial distributions of several of the larger species have been studied using various tracking devices (Cuthbert et al. 2005; Reid et al. 2014; Reid et al. 2013). We combined the tracking data from this pelagic guild to determine which areas are likely to be the most important for these and other pelagic species in the central South Atlantic Ocean.

Our main objectives were to quantify the use of distinct areas in the South Atlantic by six seabird species, and delineate areas that are used consistently by a large proportion of each population. We used international criteria and thresholds for Important Bird and Biodiversity Areas (IBAs) (BirdLife International 2010; Lascelles et al. 2016) to systematically identify areas of particular conservation relevance. Such areas could contribute to the establishment of a network of pelagic MPAs in the South Atlantic Ocean. This study is one of the few approaches to date to assess the combined use of pelagic areas by a suite of marine top predators (Delord et al. 2014; Le Corre et al. 2012; Tancell et al. 2016), and the first combining year-round data for all threatened seabirds breeding in a single island group.

\section{Methods}

\subsection{Study area}

112 The Tristan da Cunha archipelago consists of four major islands, separated by $20-400 \mathrm{~km}$ : Inaccessible ( $\left.37^{\circ} 18^{\prime} \mathrm{S}, 12^{\circ} 39^{\prime} \mathrm{W} ; 14 \mathrm{~km}^{2}\right)$, Nightingale ( $37^{\circ} 25^{\prime} \mathrm{S}, 12^{\circ} 29^{\prime} \mathrm{W} ; 4$ km²), Gough

$114\left(40^{\circ} 18^{\prime} \mathrm{S}, 9^{\circ} 57^{\prime} \mathrm{W} ; 65 \mathrm{~km}^{2}\right)$ and Tristan da Cunha $\left(37^{\circ} 07^{\prime} \mathrm{S}, 12^{\circ} 16^{\prime} \mathrm{W} ; 96 \mathrm{~km}^{2}\right)$, the only island with a permanent human population. These four islands host colonies of 25 seabird species, of which six are globally threatened. Four of these species breed exclusively in the Tristan da Cunha archipelago (Tristan Albatross Diomedea dabbenena, Atlantic Yellownosed Albatross Thalassarche chlororhynchos, Spectacled Petrel Procellaria conspicillata, Atlantic Petrel Pterodroma incerta).

For the purpose of our spatial marine prioritization, we defined our study area in the South Atlantic Ocean from $12^{\circ} \mathrm{S}$ to $80^{\circ} \mathrm{S}$, and from $65^{\circ} \mathrm{W}$ to $35^{\circ} \mathrm{E}$. 


\subsection{Tracking data}

126 We compiled the available tracking data for all six globally threatened seabird species (Critically Endangered - CR, Endangered - EN or Vulnerable - VU) that breed in the Tristan 128 da Cunha archipelago: Tristan Albatross (CR), Sooty Albatross Phoebetria fusca (EN), Atlantic Yellow-nosed Albatross (EN), Spectacled Petrel (VU), Atlantic Petrel (EN), and Northern Rockhopper Penguin Eudyptes moseleyi (EN). Most species were tracked during their breeding and non-breeding seasons from their major colonies between 2000 and 2013 on Gough and Inaccessible islands; some of these data were used in previous studies focusing on individual species (Cuthbert et al. 2005; Reid et al. 2014; Reid et al. 2013). However,

134 Northern Rockhopper Penguins were only tracked during the non-breeding season. All 380 tracks of adult birds were obtained from colonies holding a significant proportion of the world population ( $>5 \%$; Table 1). Of these tracks, 231 were collected with satellite transmitters (Platform Terminal Transmitters, PTTs), and 149 with Global Location Sensor (GLS) devices, providing a total of 70,786 bird locations. Locations collected with PTTs were filtered using the R package "argosfilter" and then interpolated to obtain hourly positions. GLS data were processed following the procedures described in detail by Phillips et al. (2004).

\subsection{Identification of marine Important Bird and Biodiversity Areas (IBAs) for each} species and season

An Important Bird and Biodiversity Area (IBA) is defined as a site known to regularly hold significant numbers of a globally threatened species, or a site that supports $>1 \%$ of the global population of a congregatory seabird species (i.e., at least $20 \%$ of a colony with more than $5 \%$ of the world population; Fishpool and Evants 2001; Lascelles et al. 2016). We analysed each dataset following the procedures developed by BirdLife International to identify marine IBAs using seabird tracking data (BirdLife International 2010; Lascelles et al. 2016). Many seabirds are known to use different areas at sea during different stages of their annual cycle, and the identification of IBAs generally benefits from analysing data separately for breeding and non-breeding seasons (Lascelles et al. 2016). However, because the six species in this study do not breed synchronously (Fig. A1), yet the management of MPAs requires the identification of areas that are important at certain times of the year, we split the data from each breeding population (species-island combination) into four seasons, defined by calendar 
months rather than the breeding cycle. This approach allowed us to identify areas that are

158

160

162

164 important for multiple species at the same time of year, and facilitates the integration of the results in dynamic management plans that consider seasonal use. We defined four seasons corresponding to four quarters of the year, and use the terms 'summer' (January - March), 'autumn' (April - June), 'winter' (July - September), and 'spring' (October - December) throughout this paper.

For each population and season we calculated the $50 \%$ kernel utilisation distribution of all individual tracks (likely corresponding to their core foraging areas; e.g. Wood et al. 2000), using the scale of interaction of the birds with the environment as estimated by first passage time analysis (Fauchald and Tveraa 2003) as a smoothing factor. We then quantified the number of overlapping core foraging ranges across all tracked individuals from each breeding population in each $0.2 \times 0.2^{\circ}$ grid cell, and identified the sites used by $\geq 20 \%$ of the tracked birds (following a conservative approach due to the limited number of individuals of each species tracked in each year; see Lascelles et al. 2016). Core foraging ranges of birds tracked with GLS were estimated using a smoothing factor of $180 \mathrm{~km}$ due to the spatial error of the geolocation method (Phillips et al. 2004), and the resulting sites were cropped (90 km inner buffer), to avoid overestimation of areas due to the large kernel radius and the error of the geolocation method.

When tracking data from multiple years were available (Tristan Albatross and Sooty Albatross in all seasons, and Atlantic Yellow-nosed Albatross in winter and spring), we identified important areas for each year separately. Although this approach reduced the sample size for each annual site identification (Table 1), it allowed us to assess consistency among years, which is important for understanding the stability of sites over time (Meier et al. 2015; Robertson et al. 2014; Tancell et al. 2016). In these cases we only considered sites overlapping in more than one year, unless sample sizes were sufficiently large in any given year (>30 individual core ranges overlapping). Finally, we calculated the percentage of overlap between the important areas identified for each species and the Exclusive Economic Zones (EEZ) of countries surrounding the South Atlantic Ocean.

\subsection{Identification of candidate MPAs across all species and seasons}

To identify priority areas for conservation in the South Atlantic, the IBAs identified for each population and season need to be combined systematically to assess which areas were the 
most important given their frequency of use by each of the target species. We used the sites identified for each population in each season (see above) in the spatial prioritization algorithm 'Zonation' (Moilanen 2007; Moilanen et al. 2005), which has been used successfully in large-scale marine applications to rank areas according to their priority for conservation (Leathwick et al. 2008; Oppel et al. 2012; Winiarski et al. 2014). The spatial prioritization is achieved by sequentially removing grid cells from the study area that have low proportions of usage by a given species in a season, and therefore the lowest conservation value. The sequential removal also considers proximity of cells to areas of high conservation priority and therefore results in a spatially constrained set of priority areas (Moilanen 2007; Moilanen et al. 2005). The approach is designed for use with multiple species, which adds weight when justifying the designation of a marine reserve (Ainley et al. 2009; Nur et al. 2011).

We used the IBAs identified for six species across four seasons, yielding a total of 22 spatial data layers (no tracking data were available for Northern Rockhopper Penguin in spring and summer). We explored the use of different weights for each data layer based on the threat status of each species (CR, EN, or VU), the quality of the dataset (GLS or PTT), and whether the layer included breeding-season data. However, as the relative weight did not materially affect the location and extent of prioritized areas (Fig. A3), each layer was assigned the same weight in the prioritization to avoid arbitrary ranking. We used a simple core-area prioritization in Zonation 4.0 to guarantee the retention of intensively used areas that were either consistently important in all seasons or of outstanding importance in some seasons. We ran the algorithm without boundary quality penalties, but with a boundary length penalty of 0.01 to provide the most biologically-detailed map of priority areas for conservation. We present the most important $10 \%$ of grid cells identified in this spatial prioritization, thus corresponding to the CBD target of protecting $10 \%$ of the global marine habitat (CBD 2010).

All analyses were carried out in R 3.1.2 (R Core Team 2016) using the approach provided by Lascelles et al. (2016) to identify IBAs and the code provided by Oppel et al. (2012) to implement the spatial prioritisation. 


\section{Results}

\subsection{Important Bird and Biodiversity Areas by species and season}

224 The at-sea areas that were used most intensively by the threatened seabirds from Tristan da Cunha archipelago (representing candidate IBAs) varied among species and seasons (Fig. 1).

226 The Tristan Albatross was the most widespread of the study species, using almost all South Atlantic waters located between $30^{\circ} \mathrm{S}$ and $45^{\circ} \mathrm{S}$. In contrast, the Sooty Albatross had a more constrained distribution, foraging within $1200 \mathrm{~km}$ of the Tristan da Cunha archipelago throughout the year (Figs. 1 and S2). The Atlantic Yellow-nosed Albatross showed a consistent use of both the waters surrounding Tristan da Cunha, and the Benguela upwelling region, while Atlantic and Spectacled petrels mostly used South American coastal waters throughout the year. The non-breeding distribution of the Northern Rockhopper Penguin (Apr-Sep) was mostly confined to the waters south-east of the Tristan da Cunha EEZ.

\subsection{Consistency of IBAs across years}

236 Despite some annual variation, many of the core areas of the albatrosses were used consistently from year to year (Fig. A2). The exception was the Atlantic Yellow-nosed

238 Albatross in winter, for which there was no overlap in the areas used in the two different years for which data were available (Fig. A2); however, given the large sample sizes in each year, both areas were retained for the prioritisation (Fig. 1 and Table 1).

\subsection{Overlap of IBAs with EEZs and current MPA network}

The overlap between core sites and national EEZs varied greatly among species (Table 2).

244 For Tristan Albatross, Sooty Albatross and non-breeding Northern Rockhopper Penguin, almost all the sites identified ( $>80 \%$ of the total area - all seasons combined) were in pelagic waters beyond national jurisdiction. In contrast, almost $50 \%$ of the core areas of Atlantic Yellow-nosed Albatross were in the EEZs of Namibia, South Africa and Tristan da Cunha.

248 The Brazilian EEZ was particularly important for Spectacled and Atlantic petrels (Table 2). Only a small proportion of the core areas that were identified overlapped with any of the existing pelagic MPAs in the South Atlantic (Fig. 1). Sooty Albatross and Atlantic Petrel 
winter core areas overlapped 5.1\% and 1.0\%, respectively, with the South Georgia and South Sandwich Islands MPA.

\subsection{Candidate MPAs important for multiple species across seasons}

We found little overlap between the most important areas used by different species (Fig. 2).

258 The exceptions were those areas around the colonies, i.e., within the Tristan da Cunha EEZ (especially during the early breeding season of most species - spring and summer) and, to a lesser extent, the coastal waters of Brazil and Uruguay (October-March), Argentine Basin (July-September) and south of the Tristan da Cunha EEZ (April-June).

The areas identified using the Zonation algorithm as those of greatest importance for the conservation of all globally threatened seabirds of Tristan da Cunha reflect the wide range of sites used by this community (Fig. 3). The areas were located around the Tristan da Cunha archipelago, coastal South America (Uruguayan and Brazilian EEZ and Argentine Basin) and in the Benguela and Agulhas currents, off the South African coast.

\section{Discussion}

Our study demonstrates that the conservation of highly mobile pelagic species cannot be achieved effectively by single countries, but requires a multi-national approach at an oceanbasin scale. Due to the central location of the Tristan da Cunha islands, the pelagic seabird species that breed there can forage over a wide area, ranging from the highly productive waters in the Benguela Current along the African coast, to the coast of southern South America, both known to be important for pelagic seabirds (Abrams and Griffiths 1981; Bugoni et al. 2008; Guilford et al. 2009). By combining tracking data from multiple species and years, covering the complete annual cycle, we have shown that this seabird community takes advantage of the central location of this archipelago by using a few regions widely distributed across the width of the South Atlantic Ocean. 
The areas that we identified meet international criteria to qualify as IBAs. We further showed that for Tristan and Sooty albatrosses, the most important areas were used consistently in at least two different years by different individuals (Fig. A2), providing additional confidence that these are used regularly by a large number of birds (BirdLife International 2010; Meier et al. 2015). Seabird populations tend to be faithful to their foraging areas and migration corridors, both at small-medium spatio-temporal scales (e.g., during the breeding season; Meier et al. 2015), and also at very large (ocean-wide) scales when released from the constraints of a breeding site (Dias et al. 2013; Dias et al. 2011; Phillips et al. 2005). Because of this site fidelity at large spatial scales, it is possible to identify sites of major importance for seabird populations that are used consistently over time (Fig. 3), and are therefore good candidates for incorporation in a network of MPAs (Montevecchi et al. 2012).

In addition to the temporally consistent use, some areas were important for more than one species. The EEZ of Tristan da Cunha was important for all species during their respective breeding seasons, and there were additional areas in Brazilian and Uruguayan waters and in the Argentine Basin where core areas of two species overlapped (Fig. 2). However, elsewhere there was generally little overlap among species in core areas used within the same seasons (Fig. 2), revealing a high degree of spatial niche segregation at a broad (ocean basin) scale. This pattern of dispersion is likely facilitated both by the central location of the Tristan da Cunha group (Abrams and Miller 1986), and the highly mobile nature of the study species, which can travel thousands of kilometres even during the breeding season (Figs. 1 and S2). Spatial segregation among species breeding sympatrically on small oceanic islands has been shown in many pelagic seabird species, and is likely a mechanism to reduce inter-specific competition (Navarro et al. 2009; Quillfeldt et al. 2013;

304 Ratcliffe et al. 2014). Although the spatial segregation of different species is of great biological interest, the comparatively low overlap of core areas has implications for the establishment of MPAs, because the candidate MPAs that we identified may omit critical areas for some species at certain times of the year. Therefore, the sites we identified should not be regarded as the definitive set of key areas for our target species; instead, they are the minimum that should be integrated in a broader MPA network for pelagic seabirds in the central South Atlantic Ocean, and should be supplemented by additional sites that are important at other times of the year and for other threatened species. 
The most important areas identified in our study in the South Atlantic are also known foraging grounds of many other threatened or near-threatened seabirds, including the

314 Wandering Albatross Diomedea exulans (VU), Northern Royal Albatross D. sanfordi (EN), Southern Royal Albatross D. epomophora (VU), Grey-headed Albatross Thalassarche

316 chrysostoma (EN), Black-browed Albatross T. melanophris (NT), Light-mantled Albatross Phoebetria palpebrata (NT), White-chinned Petrel Procellaria aequinoctialis (VU), Desertas

318 Petrel Pterodroma deserta (VU), Cape Verde Shearwater Calonectris edwardsii (NT), and Southern Rockhopper Penguin Eudyptes chrysocome (VU) (Ramírez et al. 2016; Ramos et al. 2016; Tancell et al. 2016). In addition, some sites are also important non-breeding destinations for some long-distance migrants from the North Atlantic, such as Cory's Calonectris borealis and Manx Puffinus puffinus shearwaters and Bulwer's Petrel Bulweria bulwerii (Dias et al. 2011; Guilford et al. 2009; Ramos et al. 2015), as well as other species

324 from the South Atlantic. Therefore, these sites are good candidates for MPAs in the South Atlantic, given their high biodiversity value and their potential to benefit a wide number of species from Tristan da Cunha and elsewhere, including many that are threatened.

4.2.Is MPA designation an effective tool for threatened seabirds from Tristan da Cunha?

MPAs can be an effective tool in mitigating some of the major threats to seabirds, such as fisheries bycatch and some types of pollution (Hyrenbach et al. 2000), but the establishment of MPAs in the pelagic realm has been under intense debate due to the highly dynamic nature of this environment (Devillers et al. 2014; Game et al. 2009). We found no overlap of the most important areas and existing MPAs in the South Atlantic, mostly because the existing MPAs were designated to protect other biodiversity values. Because more than half of the most important areas that we identified were in pelagic waters beyond national jurisdiction, the effective establishment and enforcement of MPAs will be politically challenging.

Many of the threatened seabirds breeding at Tristan da Cunha are susceptible to bycatch in fishing gear; the bycatch is a particularly serious threat to the Critically Endangered Tristan Albatross, but other species, such as the Sooty and Atlantic Yellownosed albatrosses and the Spectacled Petrel, are also frequently by-caught (Bugoni et al. 2008; Cuthbert et al. 2005; Wanless et al. 2009). All areas highlighted in Fig. 3 are important for at least one of these species, and some are known hotspots of seabird bycatch globally 
344 (Lewison et al. 2014). The long-line fishing effort in the most important areas reported by the International Commission for the Conservation of Atlantic Tunas (ICCAT) ranged from 11.3 to $18.1 \%$ of the fishing effort reported across the South Atlantic (south of $12^{\circ} \mathrm{S}$ ). Because our most important areas cover $17 \%$ of the area from which ICCAT data were available, the recorded effort in the most important bird areas is equal to, or slightly less than, the effort expected by chance if fishing effort was distributed randomly (Table A1). Nevertheless, and in absolute values, 11 million hooks are set on average each year in these most important sites (Table A1). Given their importance for some of the threatened seabirds mentioned above, and also for species breeding at other colonies (Jiménez et al. 2014; Tuck et al. 2011), improvements in monitoring of bycatch rates and enforcement of compliance with bycatch mitigation requirements by fisheries in these areas would be highly beneficial. Therefore, our results reinforce the need for ICCAT to strengthen and enforce regulations to reduce bycatch and to develop appropriate levels of surveillance of fishery practices by independent observers in both national and international waters, in particular within the Brazilian, Namibian and South African EEZs (Melvin et al. 2014; Phillips 2013; Small et al. 2015).

Regardless of whether MPAs are established or whether seabird protection is achieved by enforcing bycatch reduction across a wider region, it will be important to specify explicit quantitative objectives that the protection measures need to deliver in order to assess whether the management of the priority areas actually results in tangible benefits to the seabird community (McGowan and Possingham 2016).

\section{Conclusions}

366 By using a unique dataset collected over a 13-year period for all the threatened seabird species breeding in a single archipelago, we show that it is possible to find areas used consistently by a suite of highly-mobile marine predators, and that conservation and management mechanisms are required at the level of the ocean basin. The sites we identified are highly relevant for the delineation of an effective network of pelagic MPAs in the South Atlantic and for identifying potential high-risk areas of seabird bycatch, therefore meriting particular attention for monitoring of bycatch rates and compliance with recommended mitigation methods from fisheries regulators. 


\section{Acknowledgements}

376 This analysis was facilitated by the Global Seabird Tracking database (www.seabirdtracking.org) hosted by BirdLife International. We appreciate the help of a 378 large number of fieldworkers to collect tracking data, and the financial support of the UK Foreign and Commonwealth Office's Overseas Territories Environmental Programme, the Royal Society for the Protection of Birds, Birds Australia, the University of Cape Town, the Agreement on the Conservation of Albatrosses and Petrels (ACAP), and the Government of Tristan da Cunha. We appreciate logistical support from the South African Department of Environmental Affairs and Tourism through the South African National Antarctic Programme, Ovenstone Agencies Pty., and the Government of Tristan da Cunha. Research was conducted with the approval of the Government of Tristan da Cunha.

\section{References}

Abrams, R., Griffiths, A., 1981. Ecological structure of the pelagic seabird community in the Benguela Current region. Mar. Ecol. Prog. Ser. 5, 269-277.

Abrams, R.W., Miller, D.G.M., 1986. The distribution of pelagic seabirds in relation to the oceanic environment of Gough Island. S. Afr. J. Mar. Sci. 4, 125-137.

Ainley, D.G., Dugger, K.D., Ford, R.G., Pierce, S.D., Reese, D.C., Brodeur, R.D., Tynan, C.T., Barth, J.A., 2009. Association of predators and prey at frontal features in the California Current: competition, facilitation, and co-occurrence. Mar. Ecol. Prog. Ser. $389,271-294$.

Arthur, B., Hindell, M., Bester, M., Trathan, P., Jonsen, I., Staniland, I., Oosthuizen, W.C., Wege, M., Lea, M.-A., 2015. Return customers: Foraging site fidelity and the effect of environmental variability in wide-ranging Antarctic fur seals. PloS One 10, $\mathrm{e} 0120888$.

Aslan, C., Holmes, N., Tershy, B., Spatz, D., Croll, D.A., 2015. Benefits to poorly studied taxa of conservation of bird and mammal diversity on islands. Conserv. Biol. 29, 133142.

Ban, N.C., 2009. Minimum data requirements for designing a set of marine protected areas, 404 using commonly available abiotic and biotic datasets. Biodiv. Conserv. 18, 18291845. 
Barr, L.M., Possingham, H.P., 2013. Are outcomes matching policy commitments in Australian marine conservation planning? Mar. Pol. 42, 39-48.

408

BirdLife International, 2010. Marine Important Bird Areas toolkit: standardised techniques for identifying priority sites for the conservation of seabirds at-sea. http://www.birdlife.org/eu/pdfs/Marine IBA Toolkit 2010.pdf, accessed 4 November 2010.

BirdLife International, 2016. IUCN Red List for birds. http://www.birdlife.org, accessed 2 December 2016.

Block, B.A., Jonsen, I.D., Jorgensen, S.J., Winship, A.J., Shaffer, S.A., Bograd, S.J., Hazen, E.L., Foley, D.G., Breed, G.A., Harrison, A.L., Ganong, J.E., Swithenbank, A., Castleton, M., Dewar, H., Mate, B.R., Shillinger, G.L., Schaefer, K.M., Benson, S.R., Weise, M.J., Henry, R.W., Costa, D.P., 2011. Tracking apex marine predator movements in a dynamic ocean. Nature 475, 86-90.

Boonzaier, L., Pauly, D., 2016. Marine protection targets: an updated assessment of global progress. Oryx 50, 27-35.

Bugoni, L., Mancini, P.L., Monteiro, D.S., Nascimento, L., Neves, T.S., 2008. Seabird bycatch in the Brazilian pelagic longline fishery and a review of capture rates in the southwestern Atlantic Ocean. Endang. Spec. Res. 5, 137-147.

CBD, 2010. Aichi Biodiversity Targets. https://www.cbd.int/sp/targets/, accessed 30 Aug 2016.

Chown, S.L., Gaston, K.J., Williams, P.H., 1998. Global patterns in species richness of pelagic seabirds: the Procellariiformes. Ecography 21, 342-350.

Croxall, J.P., Butchart, S.H.M., Lascelles, B., Stattersfield, A.J., Sullivan, B., Symes, A., Taylor, P., 2012. Seabird conservation status, threats and priority actions: a global assessment. Bird Conserv. Int. 22, 1-34.

Cuthbert, R., Hilton, G., Ryan, P., Tuck, G.N., 2005. At-sea distribution of breeding Tristan albatrosses Diomedea dabbenena and potential interactions with pelagic longline fishing in the South Atlantic Ocean. Biol. Conserv. 121, 345-355.

Delord, K., Barbraud, C., Bost, C.-A., Deceuninck, B., Lefebvre, T., Lutz, R., Micol, T., Phillips, R.A., Trathan, P.N., Weimerskirch, H., 2014. Areas of importance for seabirds tracked from French southern territories, and recommendations for conservation. Mar. Pol. 48, 1-13. 
Devillers, R., Pressey, R.L., Grech, A., Kittinger, J.N., Edgar, G.J., Ward, T., Watson, R., 2014. Reinventing residual reserves in the sea: are we favouring ease of establishment over need for protection? Aquat. Conserv. 25, 480-504.

Dias, M.P., Granadeiro, J.P., Catry, P., 2013. Individual variability in the migratory path and stopovers of a long-distance pelagic migrant. Anim. Behav. 86, 359-364.

Dias, M.P., Granadeiro, J.P., Phillips, R.A., Alonso, H., Catry, P., 2011. Breaking the routine: individual Cory's shearwaters shift winter destinations between hemispheres and across ocean basins. Proc. R. Soc. Lond. B 278, 1786-1793.

Fauchald, P., Tveraa, T., 2003. Using first-passage time in the analysis of area-restricted search and habitat selection. Ecology 84, 282-288.

Fernandes, L., Day, J.O.N., Lewis, A., Slegers, S., Kerrigan, B., Breen, D.A.N., Cameron, D., Jago, B., Hall, J., Lowe, D., Innes, J., Tanzer, J., Chadwick, V., Thompson, L., Gorman, K., Simmons, M., Barnett, B., Sampson, K., De'Ath, G., Mapstone, B., Marsh, H., Possingham, H., Ball, I.A.N., Ward, T., Dobbs, K., Aumend, J., Slater, D.E.B., Stapleton, K., 2005. Establishing representative no-take areas in the Great Barrier Reef: Large-scale implementation of theory on Marine Protected Areas. Conserv. Biol. 19, 1733-1744.

Fishpool, L.D., Evants, M., 2001. Important bird areas in Africa and associated islands Priority sites for conservation. Pisces Publications and BirdLife International, Newbury and Cambridge, UK.

Game, E.T., Grantham, H.S., Hobday, A.J., Pressey, R.L., Lombard, A.T., Beckley, L.E., Gjerde, K., Bustamante, R., Possingham, H.P., Richardson, A.J., 2009. Pelagic protected areas: the missing dimension in ocean conservation. Trends Ecol. Evol. 24, 360-369.

Game, E.T., Grantham, H.S., Hobday, A.J., Pressey, R.L., Lombard, A.T., Beckley, L.E., Gjerde, K., Bustamante, R., Possingham, H.P., Richardson, A.J., 2010. Pelagic MPAs: The devil you know. Trends Ecol. Evol. 25, 63-64.

Gleason, M., McCreary, S., Miller-Henson, M., Ugoretz, J., Fox, E., Merrifield, M., McClintock, W., Serpa, P., Hoffman, K., 2010. Science-based and stakeholder-driven marine protected area network planning: A successful case study from north central California. Ocean Coast. Manag. 53, 52-68.

Guilford, T., Meade, J., Willis, J., Phillips, R.A., Boyle, D., Roberts, S., Collett, M., Freeman, R., Perrins, C.M., 2009. Migration and stopover in a small pelagic seabird, the Manx 
shearwater Puffinus puffinus: insights from machine learning. Proc. R. Soc. Lond. B $276,1215-1223$.

Hobday, A.J., Maxwell, S.M., Forgie, J., McDonald, J., Darby, M., Seto, K., Bailey, H., Bograd, S.J., Briscoe, D.K., Costa, D.P., Crowder, L.B., Dunn, D.C., Fossette, S., Halpin, P.N., Hartog, J.R., Hazen, E.L., Lascelles, B.G., Lewison, R.L., Poulos, G., Powers, A., 2014. Dynamic ocean management: Integrating scientific and technological capacity with law, policy and management. Stan Envtl L J 33, 125-165.

Hyrenbach, K.D., Forney, K.A., Dayton, P.K., 2000. Marine protected areas and ocean basin management. Aquat. Conserv. 10, 437-458.

Jessen, S., Chan, K., Côté, I., Dearden, P., Santo, E.D., Fortin, M.J., Guichard, F., Haider, W., Jamieson, G., Kramer, D.L., McCrea-Strub, A., Mulrennan, M., Montevecchi, W.A., Roff, J., Salomon, A., Gardner, J., Honka, L., Menafra, R., Woodley, A., 2011. Science-based Guidelines for MPAs and MPA Networks in Canada. http://cpaws.org/publications/mpa-guidelines, accessed 11 August 2014.

Jiménez, S., Phillips, R.A., Brazeiro, A., Defeo, O., Domingo, A., 2014. Bycatch of great albatrosses in pelagic longline fisheries in the southwest Atlantic: contributing factors and implications for management. Biol. Conserv. 171, 9-20.

Juffe-Bignoli, D., Burgess, N.D., Bingham, H., Belle, E.M.S., de Lima, M.G., Deguignet, M., Bertzky, B., Milam, A.N., Martinez-Lopez, J., Lewis, E., Eassom, A., Wicander, S., Geldmann, J., van Soesbergen, A., Arnell, A.P., O’Connor, B., Park, S., Shi, Y.N., Danks, F.S., MacSharry, B., Kingston, N., 2014. Protected Planet Report 2014. UNEP-WCMC, Cambridge, UK. .

Kaplan, D.M., Chassot, E., Gruss, A., Fonteneau, A., 2010. Pelagic MPAs: The devil is in the details. Trends Ecol. Evol. 25, 62-63.

Klein, C.J., Steinback, C., Watts, M., Scholz, A.J., Possingham, H.P., 2009. Spatial marine zoning for fisheries and conservation. Front Ecol Environ 8, 349-353.

Lascelles, B., Notarbartolo Di Sciara, G., Agardy, T., Cuttelod, A., Eckert, S., Glowka, L., Hoyt, E., Llewellyn, F., Louzao, M., Ridoux, V., 2014. Migratory marine species: their status, threats and conservation management needs. Aquat. Conserv. 24, 111127.

Lascelles, B.G., Taylor, P.R., Miller, M.G.R., Dias, M.P., Oppel, S., Torres, L., Hedd, A., Le Corre, M., Phillips, R.A., Shaffer, S.A., Weimerskirch, H., Small, C., 2016. Applying global criteria to tracking data to define important areas for marine conservation. Div. Distrib. 22, 422-431. 
Le Corre, M., Jaeger, A., Pinet, P., Kappes, M.A., Weimerskirch, H., Catry, T., Ramos, J.A., 506 Russell, J.C., Shah, N., Jaquemet, S., 2012. Tracking seabirds to identify potential Marine Protected Areas in the tropical western Indian Ocean. Biol. Conserv. 156, 83-

508 93.

Leathwick, J., Moilanen, A., Francis, M., Elith, J., Taylor, P., Julian, K., Hastie, T., Duffy, C., 2008. Novel methods for the design and evaluation of marine protected areas in offshore waters. Conserv. Lett. 1, 91-102.

Lewison, R.L., Crowder, L.B., Wallace, B.P., Moore, J.E., Cox, T., Zydelis, R., McDonald, S., DiMatteo, A., Dunn, D.C., Kot, C.Y., 2014. Global patterns of marine mammal, seabird, and sea turtle bycatch reveal taxa-specific and cumulative megafauna hotspots. Proc. Natl. Acad. Sci. USA 111, 5271-5276.

Ludynia, K., Kemper, J., Roux, J.-P., 2012. The Namibian Islands' Marine Protected Area: Using seabird tracking data to define boundaries and assess their adequacy. Biol. Conserv. 156, 136-145.

Mazor, T., Giakoumi, S., Kark, S., Possingham, H.P., 2014. Large-scale conservation planning in a multinational marine environment: cost matters. Ecol. Appl. 24, $1115-$ 1130.

McGowan, J., Possingham, H., 2016. Commentary: Linking movement ecology with wildlife management and conservation. Front. Ecol. Evol. 4, 1-3.

Meier, R.E., Wynn, R.B., Votier, S.C., McMinn Grivé, M., Rodríguez, A., Maurice, L., van Loon, E.E., Jones, A.R., Suberg, L., Arcos, J.M., Morgan, G., Josey, S.A., Guilford, T., 2015. Consistent foraging areas and commuting corridors of the critically endangered Balearic shearwater Puffinus mauretanicus in the northwestern Mediterranean. Biol. Conserv. 190, 87-97.

Melvin, E.F., Guy, T.J., Read, L.B., 2014. Best practice seabird bycatch mitigation for pelagic longline fisheries targeting tuna and related species. Fish Res. 149, 5-18.

Moilanen, A., 2007. Landscape zonation, benefit functions and target-based planning: unifying reserve selection strategies. Biol. Conserv. 134, 571-579.

Moilanen, A., Franco, A.M.A., Early, R.I., Fox, R., Wintle, B., Thomas, C.D., 2005. Prioritizing multiple-use landscapes for conservation: methods for large multi-species planning problems. Proc. R. Soc. Lond. B 272, 1885-1891. G., Garthe, S., Robertson, G., Phillips, R., 2012. Tracking seabirds to identify 
ecologically important and high risk marine areas in the western North Atlantic. Biol. Conserv. 156, 62-71.

540

542

544

546

548

550

552

554

556

558

560

562

564

566

568

570

Mora, C., Tittensor, D.P., Myers, R.A., 2008. The completeness of taxonomic inventories for describing the global diversity and distribution of marine fishes. Proc. R. Soc. Lond. B 275, 149-155.

Navarro, J., Forero, M.G., González-Solís, J., Igual, J.M., Bécares, J., Hobson, K.A., 2009. Foraging segregation between two closely related shearwaters breeding in sympatry. Biol Lett 5, 545-548.

Nur, N., Jahncke, J., Herzog, M.P., Howar, J., Hyrenbach, K.D., Zamon, J.E., Ainley, D.G., Wiens, J.A., Morgan, K., Ballance, L.T., Stralberg, D., 2011. Where the wild things are: predicting hotspots of seabird aggregations in the California Current System. Ecol. Appl. 21, 2241-2257.

Oppel, S., Meirinho, A., Ramírez, I., Gardner, B., O’Connell, A., Miller, P.I., Louzao, M., 2012. Comparison of five modelling techniques to predict the spatial distribution and abundance of seabirds. Biol. Conserv. 156, 94-104.

Phillips, R., 2013. Requisite improvements to the estimation of seabird by-catch in pelagic longline fisheries. Anim Conserv 16, 157-158.

Phillips, R.A., Silk, J.R.D., Croxall, J.P., Afanasyev, V., Bennett, V.J., 2005. Summer distribution and migration of nonbreeding albatrosses: Individual consistencies and implications for conservation. Ecology 86, 2386-2396.

Phillips, R.A., Silk, J.R.D., Croxall, J.P., Afanasyev, V., Briggs, D.R., 2004. Accuracy of geolocation estimates for flying seabirds. Mar. Ecol. Prog. Ser. 266, 265-272.

Quillfeldt, P., Masello, J.F., Navarro, J., Phillips, R.A., 2013. Year-round distribution suggests spatial segregation of two small petrel species in the South Atlantic. J. Biogeogr. 40, 430-441.

R Core Team, 2016. R: A language and environment for statistical computing. R Foundation for Statistical Computing, Vienna, Austria.

Ramírez, I., Paiva, V.H., Fagundes, I., Menezes, D., Silva, I., Ceia, F.R., Phillips, R.A., Ramos, J.A., Garthe, S., 2016. Conservation implications of consistent foraging and trophic ecology in a rare petrel species. Anim Conserv 19, 139-152.

Ramos, R., Ramírez, I., Paiva, V.H., Militão, T., Biscoito, M., Menezes, D., Phillips, R.A., Zino, F., González-Solís, J., 2016. Global spatial ecology of three closely-related gadfly petrels. Scientific Reports 6, 23447. 
Ramos, R., Sanz, V., Militao, T., Bried, J., Neves, V.C., Biscoito, M., Phillips, R.A., Zino, F., González-Solís, J., 2015. Leapfrog migration and habitat preferences of a small oceanic seabird, Bulwer's petrel (Bulweria bulwerii). J. Biogeogr. 42, 1651-1664.

Ratcliffe, N., Crofts, S., Brown, R., Baylis, A.M.M., Adlard, S., Horswill, C., Venables, H., Taylor, P., Trathan, P.N., Staniland, I.J., 2014. Love thy neighbour or opposites attract? Patterns of spatial segregation and association among crested penguin populations during winter. J. Biogeogr. 41, 1183-1192.

Reid, T.A., Ronconi, R.A., Cuthbert, R.J., Ryan, P.G., 2014. The summer foraging ranges of adult spectacled petrels Procellaria conspicillata. Antarct. Sci. 26, 23-32.

Reid, T.A., Wanless, R.M., Hilton, G.M., Phillips, R.A., Ryan, P.G., 2013. Foraging range and habitat associations of non-breeding Tristan albatrosses: overlap with fisheries and implications for conservation. Endang. Spec. Res. 22, 39-49.

Robertson, G., Bolton, M., Grecian, W., Monaghan, P., 2014. Inter-and intra-year variation in foraging areas of breeding kittiwakes (Rissa tridactyla). Mar. Biol. 161, 1973-1986.

Small, C., Wolfaardt, A., Tuck, G., Debski, I., Papworth, W., Kim, M.A., Favero, M., 2015. Preliminary identification of minimum elements to review the effectiveness of seabird by-catch mitigation regulations in tuna RFMOs. Collect. Vol. Sci. Pap. ICCAT 71, 2933-2943.

Smith, M.A., Walker, N.J., Free, C.M., Kirchhoff, M.J., Drew, G.S., Warnock, N., Stenhouse, 590 I.J., 2014. Identifying marine Important Bird Areas using at-sea survey data. Biol. Conserv. 172, 180-189.

Tancell, C., Sutherland, W.J., Phillips, R.A., 2016. Marine spatial planning for the conservation of albatrosses and large petrels breeding at South Georgia. Biol. Conserv. 198, 165-176.

Tittensor, D.P., Mora, C., Jetz, W., Lotze, H.K., Ricard, D., Berghe, E.V., Worm, B., 2010. 596 Global patterns and predictors of marine biodiversity across taxa. Nature 466, 10981101.

Trebilco, R., Halpern, B.S., Flemming, J.M., Field, C., Blanchard, W., Worm, B., 2011. Mapping species richness and human impact drivers to inform global pelagic conservation prioritisation. Biol. Conserv. 144, 1758-1766.

Tuck, G.N., Phillips, R.A., Small, C., Thomson, R.B., Klaer, N.L., Taylor, F., Wanless, R.M., 602 Arrizabalaga, H., 2011. An assessment of seabird-fishery interactions in the Atlantic Ocean. ICES J. Mar. Sci. 68, 1628-1637. 
Tuck, G.N., Polacheck, T., Bulman, C.M., 2003. Spatio-temporal trends of longline fishing effort in the Southern Ocean and implications for seabird bycatch. Biol. Conserv. 114, $1-27$.

Wakefield, E.D., Cleasby, I.R., Bearhop, S., Bodey, T.W., Davies, R.D., Miller, P.I., Newton, J., Votier, S.C., Hamer, K.C., 2015. Long-term individual foraging site fidelity — why some gannets don't change their spots. Ecology 96, 3058-3074.

Wanless, R.M., Ryan, P.G., Altwegg, R., Angel, A., Cooper, J., Cuthbert, R., Hilton, G.M., 2009. From both sides: Dire demographic consequences of carnivorous mice and longlining for the critically endangered Tristan albatrosses on Gough Island. Biol. Conserv. 142, 1710-1718.

Williams, R., Grand, J., Hooker, S.K., Buckland, S.T., Reeves, R.R., Rojas-Bracho, L., Sandilands, D., Kaschner, K., 2014. Prioritizing global marine mammal habitats using density maps in place of range maps. Ecography 37, 212-220.

Winiarski, K.J., Miller, D.L., Paton, P.W.C., McWilliams, S.R., 2014. A spatial conservation prioritization approach for protecting marine birds given proposed offshore wind energy development. Biol. Conserv. 169, 79-88.

Wood, A., Naef-Daenzer, B., Prince, P., Croxall, J., 2000. Quantifying habitat use in satellitetracked pelagic seabirds: application of kernel estimation to albatross locations. J. Avian Biol. 31, 278-286.

Yorio, P., 2009. Marine protected areas, spatial scales, and governance: implications for the conservation of breeding seabirds. Conserv. Lett. 2, 171-178.

Žydelis, R., Wallace, B.P., Gilman, E.L., Werner, T.B., 2009. Conservation of marine megafauna through minimization of fisheries bycatch. Conserv. Biol. 23, 608-616. 
Table 1: Summary of the tracking data used to identify important areas for conservation in the South Atlantic Ocean. N indicates the number of individual tracks of adult birds. For Atlantic Petrels and Northern Rockhopper Penguins, data from multiple years were pooled due to small sample sizes. Values in parentheses correspond to the percentage of the world population breeding on each island (following ACAP species assessments [http://acap.aq/en/acap-species], and BirdLife International (2016) for Atlantic Petrel and Northern Rockhopper Penguin).

\begin{tabular}{|c|c|c|c|c|c|c|c|c|c|c|c|c|c|}
\hline \multirow[t]{2}{*}{ Species } & \multirow[t]{2}{*}{ Colony } & \multicolumn{3}{|c|}{ Summer (Jan-Mar) } & \multicolumn{3}{|c|}{ Autumn (Apr-Jun) } & \multicolumn{3}{|c|}{ Winter (Jul-Sep) } & \multicolumn{3}{|c|}{ Spring (Oct-Dec) } \\
\hline & & Year & Device & $\mathrm{N}$ & Year & Device & $\mathrm{N}$ & Year & Device & $\mathrm{N}$ & Year & Device & $\mathrm{N}$ \\
\hline \multirow[t]{5}{*}{ Tristan Albatross } & \multirow{5}{*}{$\begin{array}{l}\text { Gough } \\
(\sim 100 \%)\end{array}$} & 2001 & PTT & 31 & 2001 & PTT & 81 & 2001 & PTT & 24 & 2004 & GLS & 24 \\
\hline & & 2005 & GLS & 18 & 2005 & GLS & 13 & 2004 & GLS & 14 & 2005 & GLS & 7 \\
\hline & & 2006 & GLS & 12 & 2010 & GLS & 12 & 2005 & GLS & 12 & 2010 & GLS & 12 \\
\hline & & 2011 & GLS & 12 & 2011 & GLS & 11 & 2010 & GLS & 12 & 2011 & GLS & 10 \\
\hline & & 2012 & GLS & 10 & & & & 2011 & GLS & 10 & & & \\
\hline \multirow{2}{*}{$\begin{array}{l}\text { Atlantic Yellow-nosed } \\
\text { Albatross }\end{array}$} & \multirow{2}{*}{$\begin{array}{l}\text { Gough } \\
(\sim 8 \%)\end{array}$} & \multirow[t]{2}{*}{2005} & \multirow{2}{*}{ GLS } & \multirow[t]{2}{*}{40} & \multirow{2}{*}{2005} & \multirow[t]{2}{*}{ GLS } & \multirow[t]{2}{*}{54} & 2004 & GLS & 30 & 2000 & PTT & 7 \\
\hline & & & & & & & & 2005 & GLS & 31 & 2004 & GLS & 90 \\
\hline \multirow[t]{4}{*}{ Sooty Albatross } & \multirow{4}{*}{$\begin{array}{l}\text { Gough } \\
(\sim 30 \%)\end{array}$} & 2004 & GLS & 20 & 2004 & GLS & 12 & 2004 & GLS & 17 & 2003 & GLS & 22 \\
\hline & & 2005 & GLS & 7 & 2005 & GLS & 6 & 2005 & GLS & 6 & 2004 & GLS & 7 \\
\hline & & 2006 & GLS & 6 & & & & & & & 2005 & GLS & 6 \\
\hline & & 2007 & PTT & 5 & & & & & & & & & \\
\hline Spectacled Petrel & $\begin{array}{l}\text { Inaccessible } \\
(100 \%)\end{array}$ & 2010 & PTT & 8 & 2010 & PTT & 5 & - & - & - & 2009 & PTT & 8 \\
\hline Atlantic Petrel & Gough $(\sim 100 \%)$ & $2011-12$ & GLS & 7 & $2010-12$ & GLS & 7 & $2010-12$ & GLS & 7 & 2009-11 & GLS & 7 \\
\hline $\begin{array}{l}\text { Northern Rockhopper } \\
\text { Penguin }\end{array}$ & Gough (24\%) & - & - & - & $2011-12$ & GLS & 9 & $2011-12$ & GLS & 9 & - & - & - \\
\hline
\end{tabular}


Table 2: Percentage of overlap between the distribution of threatened seabirds breeding in Tristan da Cunha (areas used by $>20 \%$ of the population of each species at Tristan da Cunha for which tracking data were available; see Table 1) and Exclusive Economic Zones and Areas Beyond National Jurisdiction (ABNJ, \% in relation to the total area used by each species).

\begin{tabular}{|c|c|c|c|c|c|c|}
\hline & $\begin{array}{c}\text { Tristan } \\
\text { Albatross }\end{array}$ & $\begin{array}{l}\text { Atlantic-Yellow- } \\
\text { nosed Albatross }\end{array}$ & $\begin{array}{c}\text { Sooty } \\
\text { Albatross }\end{array}$ & $\begin{array}{c}\text { Spectacled } \\
\text { Petrel }^{1}\end{array}$ & $\begin{array}{c}\text { Atlantic } \\
\text { Petrel }\end{array}$ & $\begin{array}{c}\text { Northern Rockhopper } \\
\text { Penguin }^{2}\end{array}$ \\
\hline Tristan da Cunha & 19.3 & 16.4 & 13.9 & 26.9 & 3.3 & 0.2 \\
\hline Brazil & & & & 10.8 & 10.4 & \\
\hline Uruguay & & & & 7.2 & 3.9 & \\
\hline Argentina & & & & 8.1 & 5.2 & \\
\hline Falkland Islands & & & & & 5.6 & \\
\hline South Georgia and South & & & 1.8 & & 0.4 & \\
\hline \multicolumn{7}{|l|}{ Sandwich Islands } \\
\hline Angola & & 2.3 & & & & \\
\hline Namibia & & 19.1 & & & & \\
\hline South Africa & 0.1 & 10.1 & & & & \\
\hline ABNJ & 80.6 & 52.1 & 84.3 & 47.0 & 71.2 & 99.8 \\
\hline Total area $\left(\times 1000 \mathrm{~km}^{2}\right)$ & 3256 & 2800 & 2153 & 1115 & 2885 & 761 \\
\hline
\end{tabular}

1 - Excluding winter (see Methods and Table 1)

2 - Only non-breeding period (autumn and winter) considered (see Methods and Table 1) 
Figure captions:

642

Figure 1: Important areas used by $>20 \%$ of the tracked population of six globally threatened 644 seabirds from the Tristan da Cunha archipelago based on tracking data collected between 2001 and 2013. Important areas were identified for each season, which are indicated by 646 different colours. Currently existing marine protected areas are shaded grey. Light grey lines indicate the Exclusive Economic Zones of all adjacent countries and territories.

Figure 2: Season-specific Important Bird and Biodiversity Areas for globally threatened 650 pelagic seabirds breeding in the Tristan da Cunha archipelago, based on tracking data collected between 2001 and 2013 (Fig. 1). Dark red borders indicate sites used by more than one species, the red shading gradient indicates the number of species for which an area was considered important. Light grey lines indicate the Exclusive Economic Zones of all adjacent 654 countries and territories.

656 Figure 3. Marine areas in the South Atlantic Ocean with the highest value for the conservation of six globally threatened seabird species breeding in the Tristan da Cunha 658 archipelago. Areas were identified using the systematic conservation-planning algorithm 'Zonation' (see text for details); the shading reflects the priority for conservation. Only the 660 $10 \%$ most important areas (i.e., those scoring $\geq 0.9$ on a scale from 0 to 1 ) are shown. Light grey lines indicate the Exclusive Economic Zones of all adjacent countries and territories. 


\section{Supporting Information}

\section{Using globally threatened pelagic birds to identify priority sites for marine conservation in the South Atlantic Ocean}

Maria P. Dias ${ }^{1, *}$, Steffen Oppel ${ }^{2}$, Alexander L. Bond ${ }^{2}$, Ana P. B. Carneiro ${ }^{1}$, Richard J.

Cuthbert $^{2}$, Jacob Gonzáles-Solís ${ }^{3}$, Ross Wanless ${ }^{4}$, Trevor Glass ${ }^{5}$, Ben Lascelles ${ }^{1}$, Cleo Small $^{2}$, Richard A. Phillips ${ }^{6}$ and Peter G. Ryan ${ }^{7}$

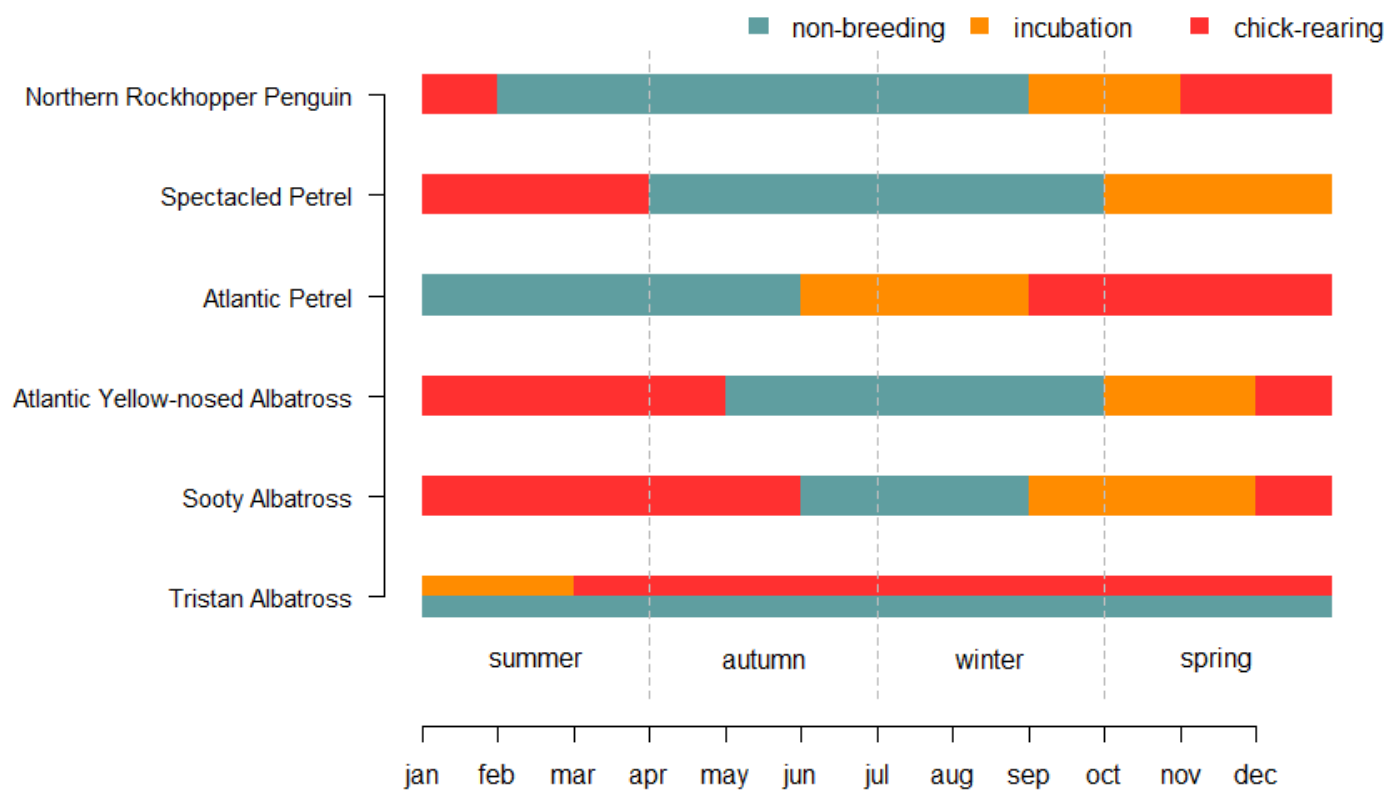

Figure A1: Breeding cycle of the six threatened seabirds at the Tristan da Cunha archipelago, and overlap with each season. Tristan Albatrosses are biennial breeders, so the plot reflects the alternation between breeding and sabbatical years. Based on ACAP species assessments (available at http://acap.aq/en/acap-species), Cuthbert (2004) for Atlantic Petrel and Cuthbert (2013) for Northern Rockhopper Penguin. this and other burrowing petrels on Gough Island, South Atlantic Ocean. Emu 104, 221-228. 

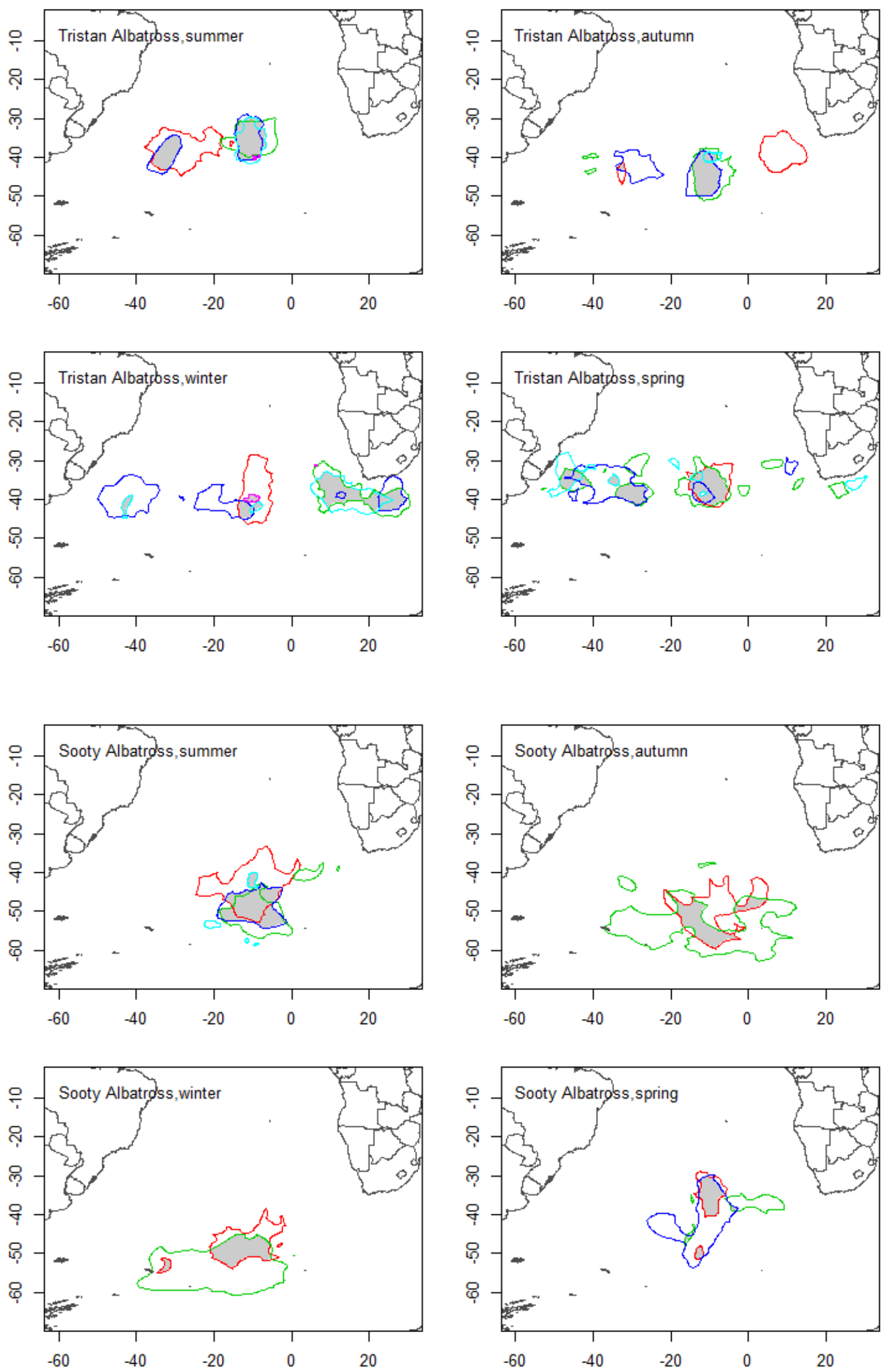

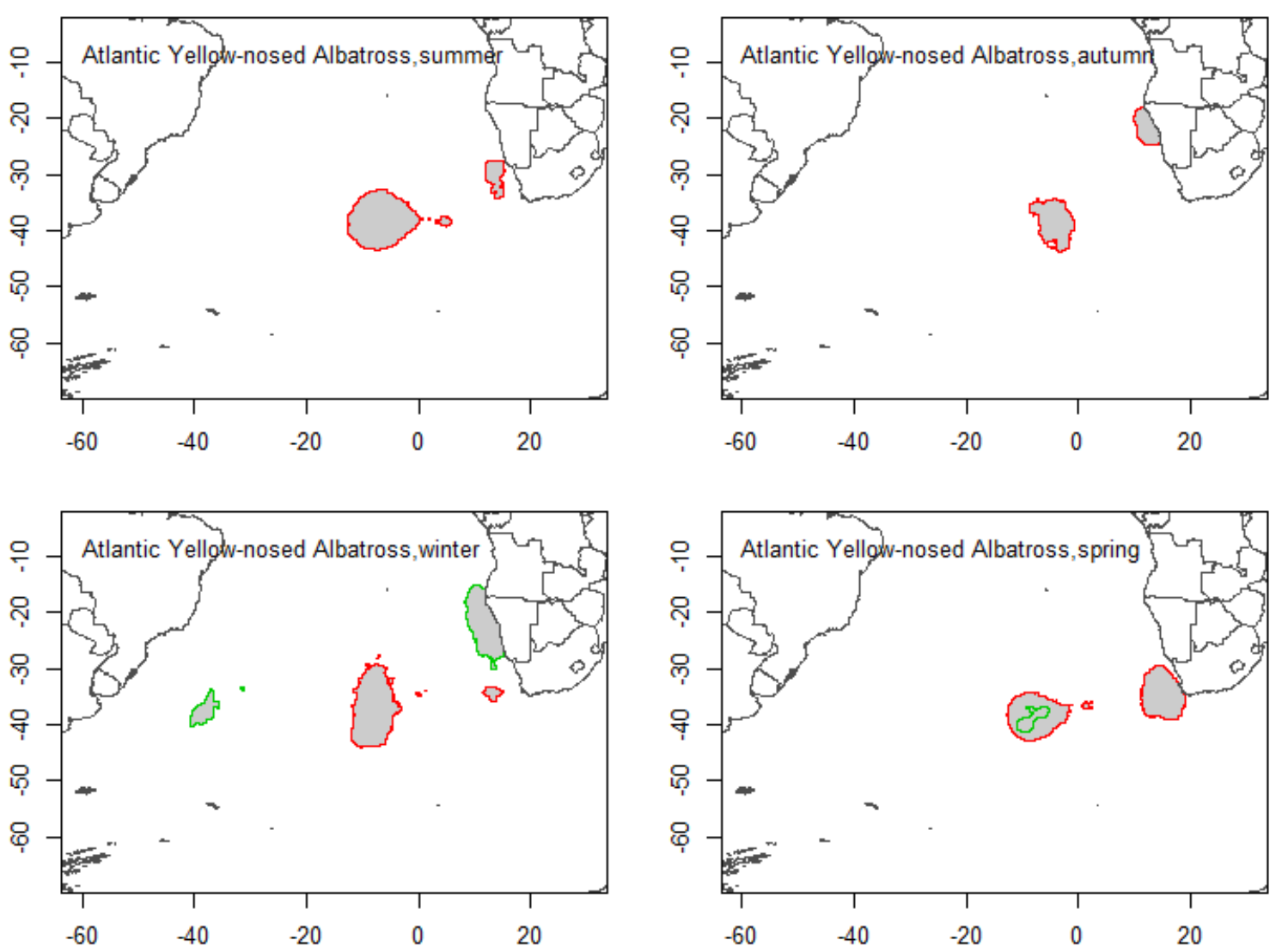

Figure A2: Spatial overlap of important areas identified for three globally threatened seabird

24 species tracked from the Tristan da Cunha archipelago in more than one year. Each year is shown in a different colour, see Table 1 for details of sample sizes and tracking devices. Grey areas correspond to the IBA for each species (corresponding to the overlap of 2 or more years of data, when available). 

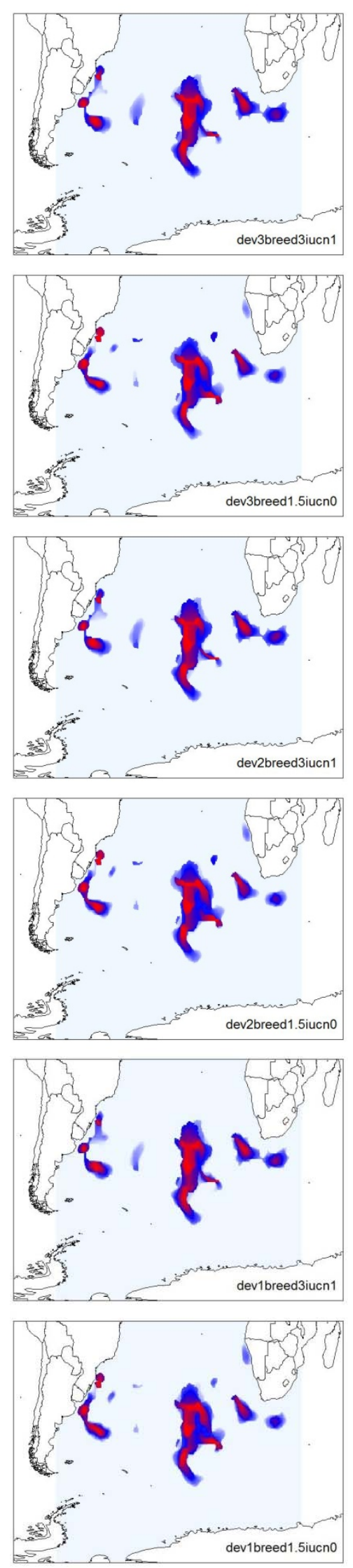
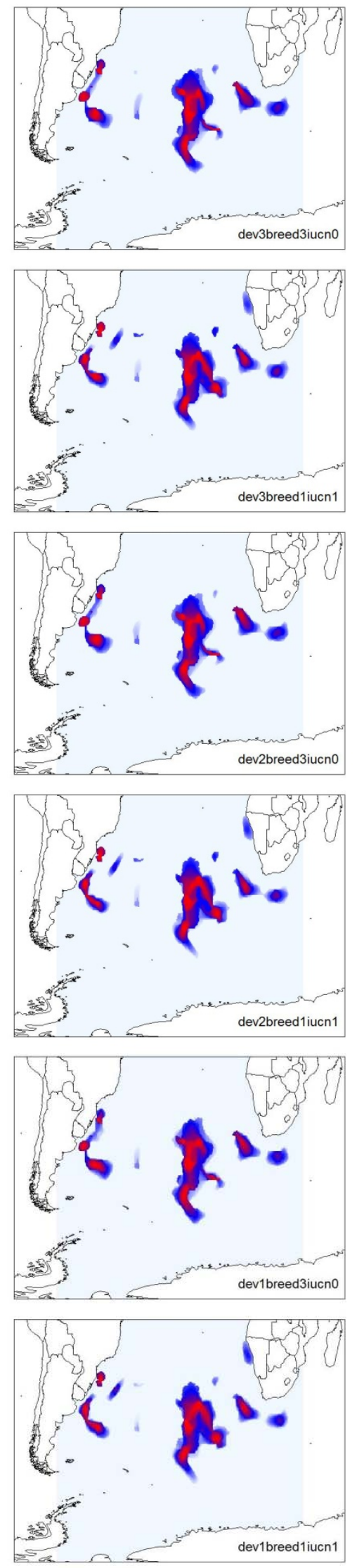
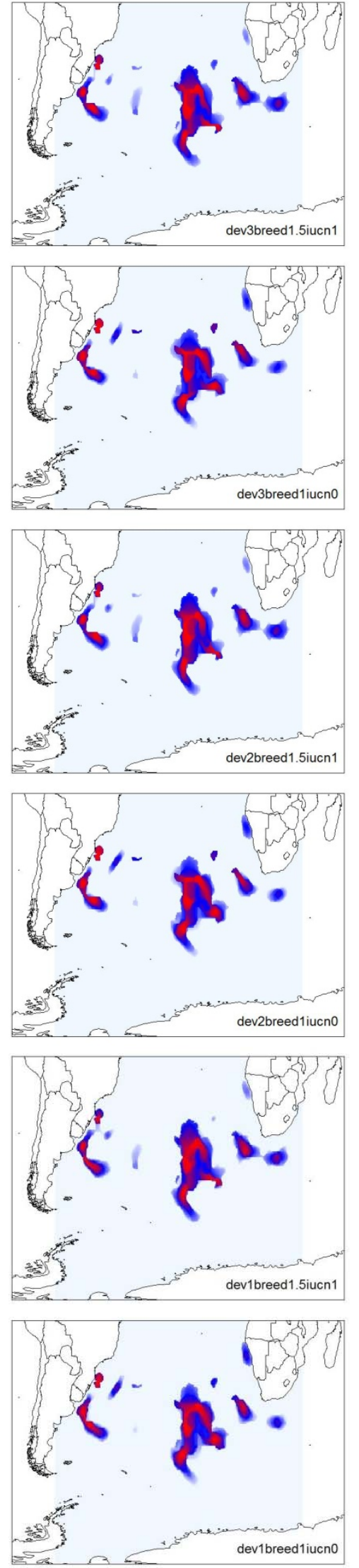
32 Figure A3: Marine areas in the South Atlantic Ocean with the highest value for the conservation of six globally threatened seabird species breeding in the Tristan da Cunha

34 archipelago, derived from various iterations of the spatial prioritisation algorithm using arbitrary weights for device type ('dev', giving higher weight to PTT than GLS), global threat

36 status ('IUCN', ranking $\mathrm{CR}>\mathrm{EN}>\mathrm{VU}$ ), and breeding season ('breed', giving higher weight to the breeding season than the non-breeding season). Colour scheme is analogous to Figure 3

38 in the main text; only the $10 \%$ most important areas (i.e., those scoring $\geq 0.9$ on a scale from 0 to 1$)$ are shown. 
42 Table S1: Fishing effort (millions of hooks deployed during the years 2000-2014) reported by the International Commission for the Conservation of Atlantic Tunas (ICCAT; obtained at

$44 \mathrm{https}: / / \mathrm{www} . \mathrm{iccat} . \mathrm{int} / \mathrm{en} / \mathrm{accesingdb} . \mathrm{htm}$ on 15 Nov 2016) within the entire South Atlantic study area, and within the priority sites identified based on the IBAs for threatened seabirds

46 breeding in Tristan da Cunha. Because the ICCAT data do not cover our entire study area, we estimated a "random fishing index" to take into account the difference in the areas being

48 compared. The random fishing index was calculated as (total number of hooks in South Atlantic Study Area/ number of hooks within the priority area)/proportion of ICCAT fishing effort data covered by the priority area (fixed value $=0.17$ ). The random effort index indicates whether fishing effort within the priority area is greater $(>1)$ or smaller $(<1)$ than expected by chance if fishing effort was distributed randomly.

\begin{tabular}{lccc}
\hline Year & $\begin{array}{c}\text { Estimated number of hooks } \\
\text { within South Atlantic study } \\
\text { area [millions] }\end{array}$ & $\begin{array}{c}\text { Estimated number of } \\
\text { hooks within the 10\% } \\
\text { priority area [millions] }\end{array}$ & $\begin{array}{c}\text { Random } \\
\text { fishing index }\end{array}$ \\
\hline 2000 & 90.53 & 14.06 & 0.90 \\
2001 & 110.53 & 19.96 & 1.05 \\
2002 & 98.16 & 14.95 & 0.89 \\
2003 & 78.65 & 11.37 & 0.85 \\
2004 & 82.97 & 11.92 & 0.84 \\
2005 & 72.99 & 9.66 & 0.78 \\
2006 & 83.65 & 9.47 & 0.67 \\
2007 & 74.42 & 9.69 & 0.75 \\
2008 & 68.14 & 9.19 & 0.79 \\
2009 & 69.96 & 8.26 & 0.69 \\
2010 & 70.41 & 8.45 & 0.69 \\
2011 & 81.75 & 9.31 & 0.67 \\
2012 & 66.43 & 9.9 & 0.96 \\
2013 & 66.02 & 9.86 & 0.88 \\
2014 & 50.67 & 6.6 & 0.76 \\
\hline
\end{tabular}


Figure 1
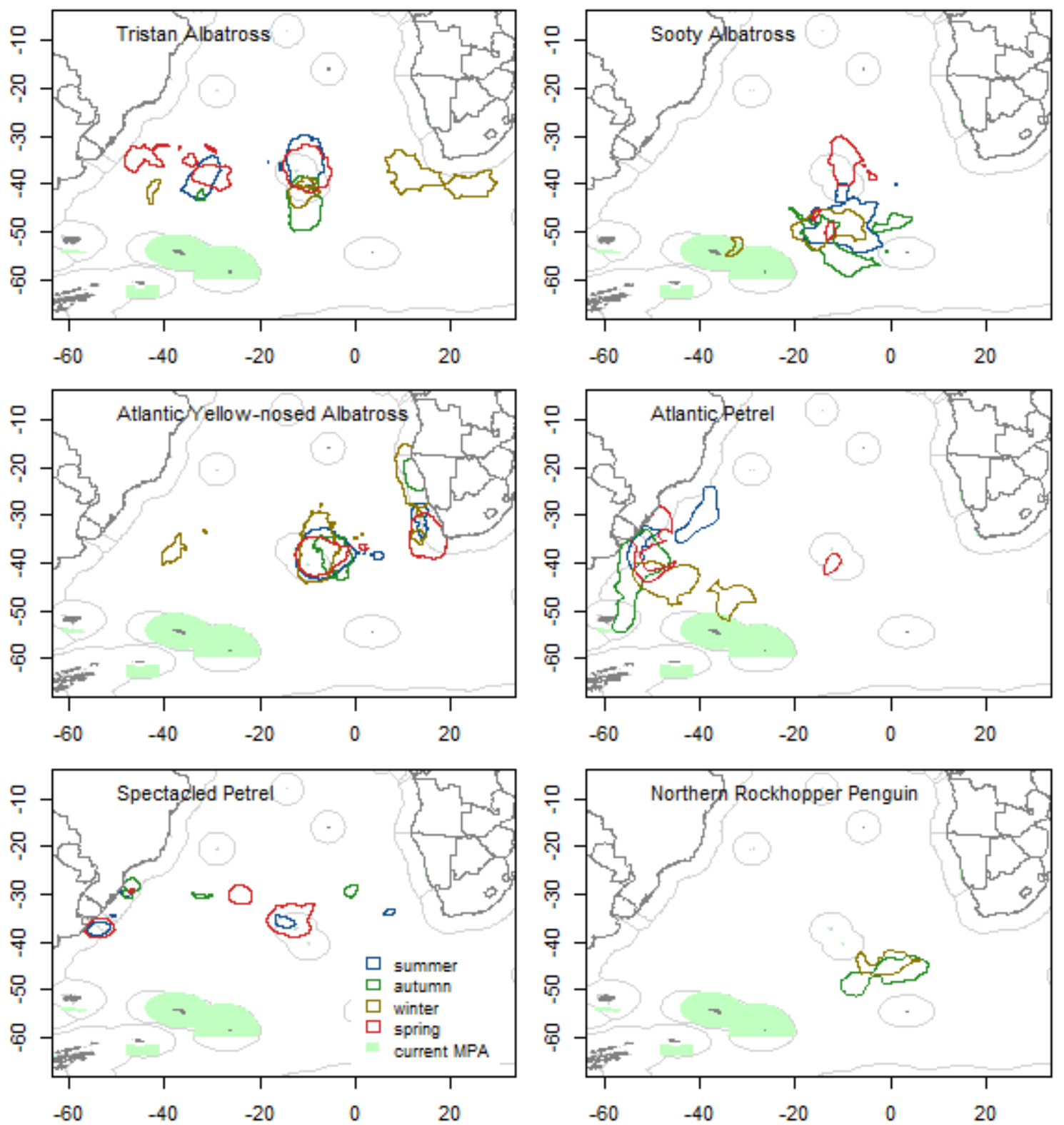
Figure 2
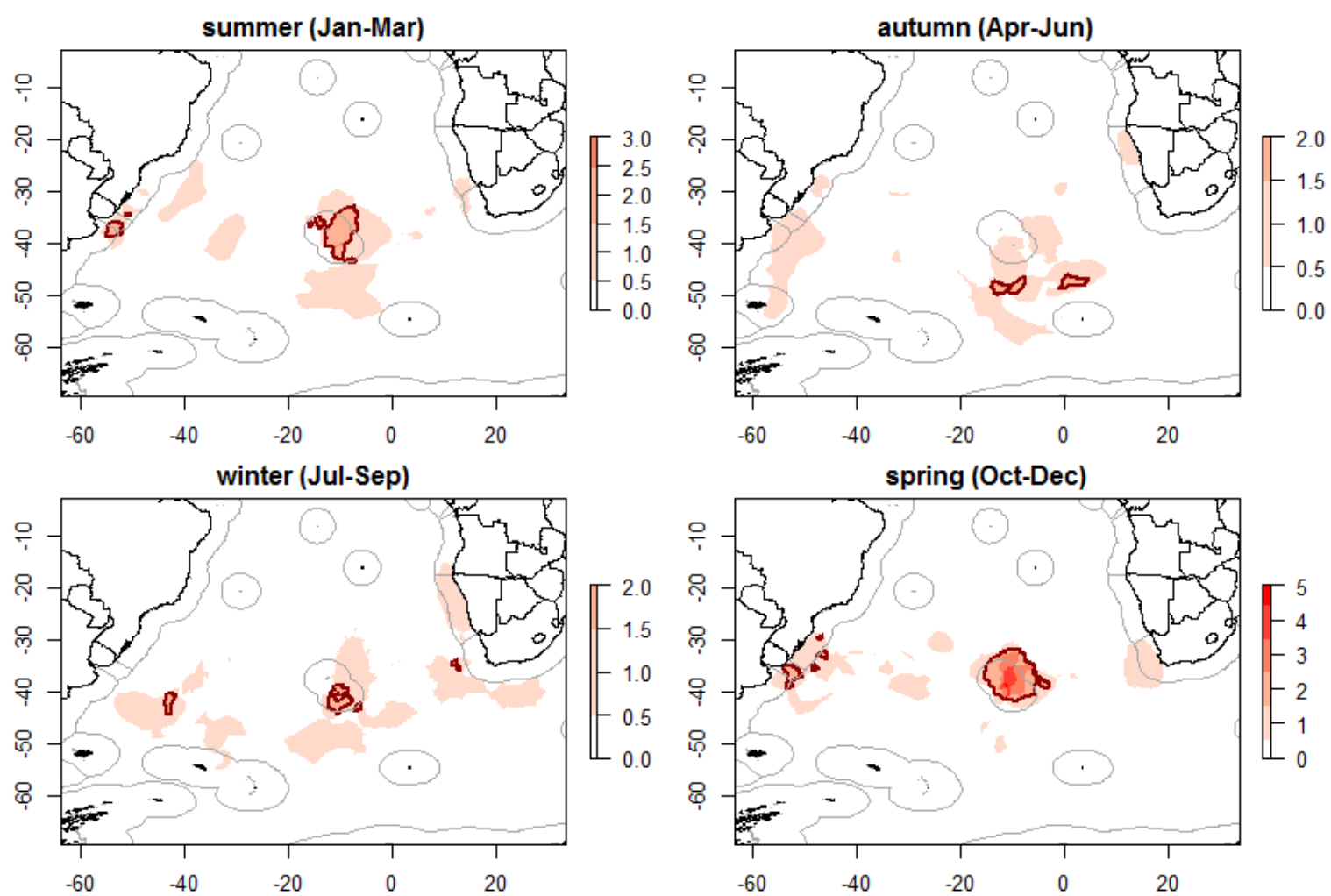

6 
Figure 3

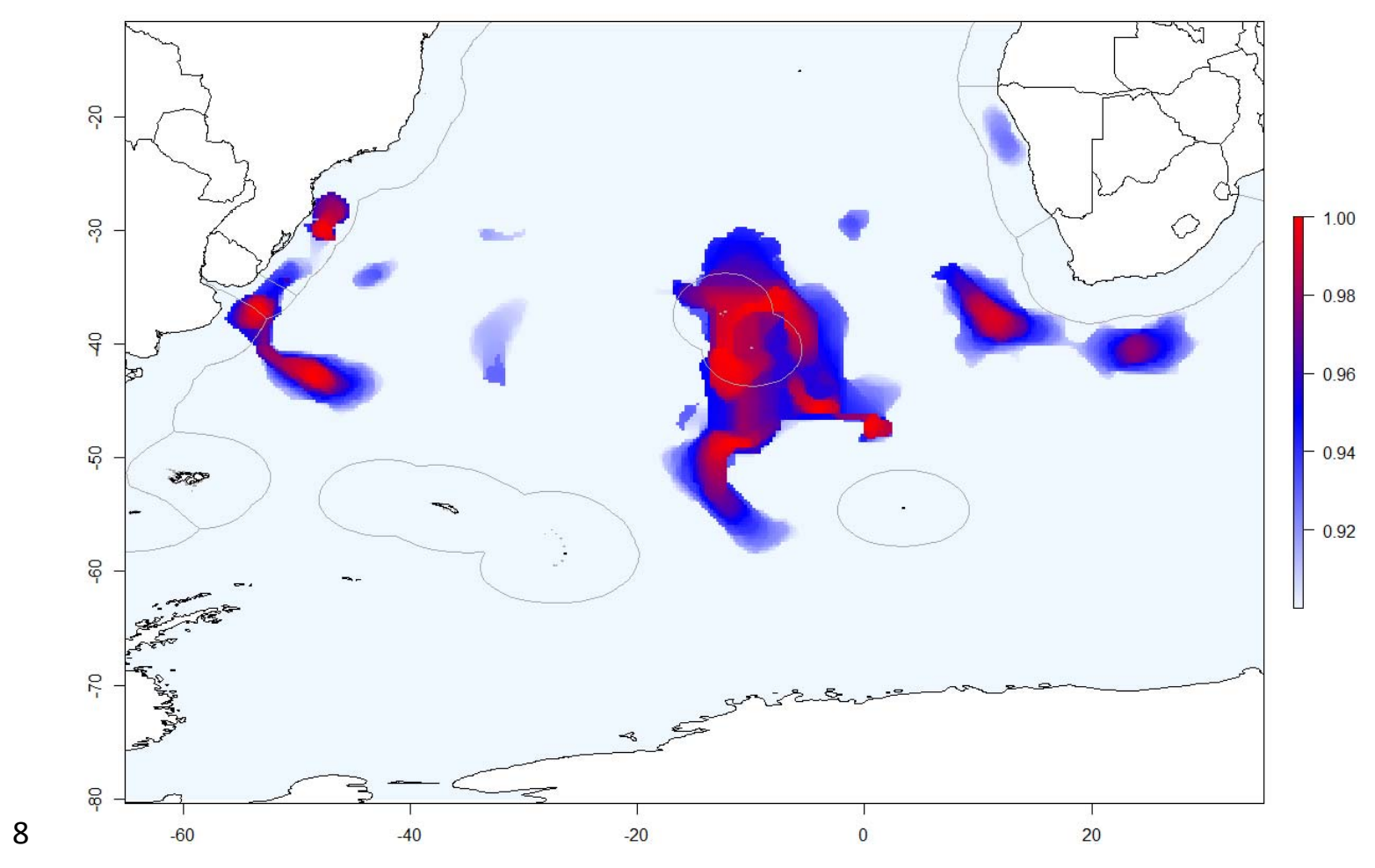

